\begin{tabular}{cc|c}
\hline Tar. Bil. Der. & Tarım Bilimleri Dergisi & Journal of Agricultural Sciences \\
& $\begin{array}{c}\text { Dergi web sayfası: } \\
\text { www.agri.ankara.edu.tr/dergi }\end{array}$ & Journal homepage: \\
& www.agri.ankara.edu.tr/journal
\end{tabular}

\title{
Avcı Akar Neoseiulus californicus (McGregor) (Acari: Phytoseiidae) Popülasyonlarının Milbemectin’e Karşı Direnç Düzeyleri, Sinerjistleri ve Detoksifikasyon Enzimlerinin Belirlenmesi
}

\author{
Sibel YORULMAZ SALMAN ${ }^{\text {a }}$, Yasemin YAMAN ${ }^{\text {a }}$, Fatma AYDINLI ${ }^{\mathrm{a}}$, Recep AY ${ }^{\mathrm{a}}$ \\ ${ }^{a}$ Süleyman Demirel Üniversitesi, Ziraat Fakültesi, Bitki Koruma Bölümü, Isparta, TÜRKIYE
}

\section{ESER BILGISİ}

Araştırma Makalesi-Bitkisel Üretim ～https://doi.org/10.1501/Tarimbil_0000001246

Sorumlu Yazar: Sibel YORULMAZ SALMAN, E-posta: sibelyorulmaz@sdu.edu.tr, Tel: +90 (246) 2114866

Geliş Tarihi: 25 Haziran 2013, Düzeltmelerin Gelişi: 30 Temmuz 2013, Kabul:16 Ağustos 2013

\begin{abstract}
ÖZET
Bu çalışmada, Isparta ili elma bahçelerinden 2012 yılında toplanan 3 Neoseiulus californicus popülasyonunun milbemectin'e karşı duyarlılık düzeylerinin ilaçlama kulesi-yaprak disk metoduyla belirlenmesi amaçlanmıştır. $N$. californicus popülasyonlarının milbemectin'e karşı duyarlılık düzeyleri tarla popülasyonlarının LC $_{50}$ değerinin hassas popülasyonun $\mathrm{LC}_{50}$ değerine oranlanmasıyla bulunmuştur. Ayrıca milbemectin üzerinde piperonyl butoxide (PBO), S-Benzyl-O,O-diisopropyl phosphorothioate (IBP) ve diethylmaleate (DEM) sinerjistlerinin sinerjistik etkileri belirlenmiştir. Eğirdir, Eyüpler ve Gelendost popülasyonlarında milbemectin'e karşı sırasıyla 7.20, 6.52 ve 7.35 kat direnç oranları belirlenmiştir. Eğirdir, Eyüpler ve Gelendost popülasyonlarında PBO, IBP ve DEM sinerjistik etki oranları sırasiyla $<1,1.59$ ve 1.85 kat; $1.81,1.86$ ve 1.82 kat ve $1.87,1.52$ ve 2.25 kat olarak belirlenmiştir. $N$. californicus popülasyonlarında glutathion S-transferaz (GST), monooksigenaz (P450) ve asetilkolinesteraz (AChE) enzimleri kinetik yöntemle, esteraz enzimi elektroforez ve kinetik yöntemlerle belirlenmiştir. $N$. californicus popülasyonlarının esteraz, glutathion S-transferaz (GST), monooksigenaz (P450) ve asetilkolinesteraz (AChE) enzim seviyeleri sirasiyla 8.86$11.64,2.11-3.82,0.02-0.05$ ve 0.01-0.02 $\mathrm{mOD} \mathrm{min}{ }^{-1} \mathrm{mg}^{-1}$ protein arasında değişmiştir.

Anahtar Kelimeler: Neoseiulus californicus; Milbemectin; Direnç; Sinerjist; Detoksifikasyon enzimleri
\end{abstract}

\section{Determination of the Resistance Levels, Synergists and Detoxification Enzymes of the Predatory Mite Neoseiulus californicus (McGregor) (Acari: Phytoseiidae) Populations to Milbemectin}

\section{ARTICLE INFO}

Research Article-Crop Production

Corresponding Author: Sibel YORULMAZ SALMAN, E-mail: sibelyorulmaz@sdu.edu.tr, Tel: +90 (246) 2114866

Received: 25 June 2013, Received in Revised Form: 30 July 2013, Accepted: 16 August 2013 


\begin{abstract}
The aim of this study was to determine the sensitivity levels of 3 Neoseiulus californicus populations collected from the apple orchards located in Isparta province in 2012 to milbemectin by using spray tower-leaf disk method. The sensitivity of $N$. californicus populations to milbemectin were calculated by proportioning the $\mathrm{LC}_{50}$ levels of the field populations to that of the susceptible population. Moreover, the synergistic effects of the piperonyl butoxide (PBO), S-Benzyl-O,Odiisopropyl phosphorothioate (IBP) and diethylmaleate (DEM) synergists on milbemectin were determined. Resistance ratios of Eğirdir, Eyüpler and Gelendost populations were determined to be 7.20, 6.52 and 7.35 fold to milbemectin, respectively. The synergistic effects of PBO, IBP and DEM in Eğirdir, Eyüpler and Gelendost populations were found as $<1,1.59$ and 1.85 fold; $1.81,1.86$ and 1.82 fold; $1.87,1.52$ and 2.25 fold, respectively. Enzymes of glutathione S-transferase (GST), monooxygenase (P450) and acetylcholinesterase (AChE) in N. californicus popluations were determined by using kinetic method; and the enzyme of esterase was determined by using the electrophoresis and kinetic methods. The enzyme levels of esterase, glutathion S-transferase (GST), monooxygenase (P450) and asetilkolinesterase (AChE) of N. californicus populations were changed from 8.86 to $11.64,2.11$ to 3.82, 0.02 to 0.05 and 0.01 to $0.02 \mathrm{mOD}$ $\min ^{-1} \mathrm{mg}^{-1}$ proteins, respectively.
\end{abstract}

Keywords: Neoseiulus californicus; Milbemectin; Resistance; Synergist; Detoxification enzymes

(C) Ankara Üniversitesi Ziraat Fakültesi

\section{Giriş}

Zararlı kırmızı örümcekler dünya üzerindeki kültür bitkisi üretim alanlarında önemli ürün kayıplarına neden olmaktadır (Tsagkarakou et al 1999). Kırmızı örümceklerin üreme potansiyellerinin yüksek, yaşam döngülerinin kısa olması ve pestisitlere karşı hızla direnç geliştirmeleri nedeniyle savaşımda alternatif mücadele yöntemlerine gerek duyulmaktadır (Stumpf \& Nauen 2001; Van Leeuwen et al 2005). Phytoseiidae familyası içerisinde yer alan avcı akar türleri de seralarda, bağ alanlarında, meyve ve turunçgil bahçelerinde zararlı akar türlerini baskı altına alabilmektedir (Castognoli \& Falchini 1993; Gotoh et al 2006). Bu familya içerisinde bulunan Neoseiulus californicus alternatif besinlerinin bulunması nedeniyle fitofag akarların kontrolünde kullanılan etkin bir avc1 akar türüdür (Castagnoli \& Simoni 1999). N. californicus'un çeşitli ülkelerde ticari rrklarının bulunmasının yanı sıra Avrupa, Güney Afrika, Doğu Asya, Kuzey ve Güney Amerika gibi ülkelerde de doğal popülasyonları bulunmaktadır (Canlas et al 2006). N. californicus'un doğal popülasyonu, Türkiye'de ilk kez Aydın'ın Kuşadası ilçesinde çilek, şeftali, fasulye ve biber üzerinden bulunmuştur (Çakmak \& Çobanoğlu 2006). Daha sonraki yıllarda Isparta'da bulunan elma bahçelerinde de $N$. californicus varlığı tespit edilmiştir (Yorulmaz \& Ay 2012).

Günümüzde zararlılarla savaşımda uygulanan entegre mücadele programları içerisinde alternatif savaşım yöntemleri kimyasal kullanımı ile desteklenmediğinde verimde ve ürün kalitesinde azalma meydana gelmektedir.Ancak akar mücadelesi için yoğun pestisit kullanılan alanlarda bulunan Phytoseidaee familyası içerisindeki avcı akar türleri de dolaylı olarak kimyasallardan etkilenmektedir. Uygulanan kimyasalların avcı akarlar üzerinde olumsuz yan etkileri olabileceği gibi, zaman zaman bu türlerin kimyasallara karşı direnç geliştirdikleri de bilinmektedir (Tirello et al 2012). Bonafos et al (2007) bağ alanlarından topladıkları Typlodromus pyri Scheuten ve Amblyseius andersoni (Acari: Phytoseiidae) popülasyonlarının deltamethrin, lamda-cyhalothrin ve chlorpyrifos-ethly'e karşı orta düzeyden yüksek düzeye kadar değişen oranlarda dirençli bulmuşlardır. Laboratuvar koşullarında yapılan çalışmalarda doğal düşmanların seleksiyon baskısı sonucunda direnç geliştirebileceğini göstermektedir. Sato et al (2000) Amblyseius womersleyi Schicha (Acari:Phytoseiidae)'nin methidathion ile laboratuvarda $4 \mathrm{kez}$ seleksiyon sonrası direncinin 311 kat artığını belirlemişlerdir. Auger et al (2005) ise mancozeb ile 10 kere 
seleksiyon yaptıkları $T$. pyri'nin popülasyonunda direncin 73 kat arttığını bulmuşlardır. Bazı pestisitlere karşı direnç geliştiren doğal düşmanların ileride entegre mücadele programları içerisinde kullanılabilecekleri düşünülmektedir. Çünkü entegre mücadelenin içerisinde yer alan pestisit direnç yönetim programlarında zararlı türlerde direnç gelişimi istenmezken; doğal düşmanların pestisitlere karşı dayanıklı olmaları istenmektedir (Dunley et al 1991).

Akarisitler içerisinde abamectin ile aynı grupta yeralan milbemectin toprakmikroorganizmalarından Streptomyces avermitilis ve Streptomyces hygroscopius'dan elde edilmektedir (Fritz et al 1979; Clark et al 1995; Van Leeuwen et al 2010). Milbemectin abamectin ile benzer şekilde akarisit özelliğe sahiptir ve fitofag akarların yumurta, larva ve ergin dönemlerinde uygulanmaktadır (Bloomguist 2001; Dekeyser 2005; Nicastro et al 2010). Milbemectin ülkemizde sebze, süs bitkileri ve elma bahçelerinde Tetranychus urticae ve Panonychus ulmi (Acari: Tetranychidae)'ye karşı kullanılmaktadır.

$\mathrm{Bu}$ çalışmada, zararlı kırmızı örümceklerin önemli bir avcısı olan $N$. californicus'un elma bahçelerinden toplanan popülasyonlarının milbemectin'e karşı duyarlılık düzeyleri biyoassay ve biyokimyasal yöntemlerle incelenerek direnç düzeyleri ve direnç mekanizmalarının belirlenmesi amaçlanmıştır.

\section{Materyal ve Yöntem}

\subsection{Neoseiulus californicus popülasyonlarının toplanmasl ve yetiştirilmesi}

Çalışmanın ana materyalini 2012 yılında Isparta ili Eğirdir ve Gelendost ilçelerinden toplanan $N$. californicus popülasyonları oluşturmuştur (Çizelge 1). Laboratuvara getirilen popülasyonlar temiz barbunya bitkileri üzerine aktarılarak kültüre alınmıştır. Isparta ili Eğirdir ilçesinde bulunan Meyvecilik Araştırma İstasyon Müdürlügünndeki organik elma bahçesinden 2008 yılında toplanılarak Süleyman Demirel Üniversitesi Ziraat Fakültesi
Bitki Koruma Bölümünde bulunan iklim odasında yetiştirilen $N$. californicus popülasyonu hassas popülasyon olarak kullanılmıştır. $N$. californicus popülasyonları, avcı akarların beslenmesi amacıyla yetiştirilen $T$. urticae ve barbunya bitkileri $26 \pm 1{ }^{\circ} \mathrm{C}$ sicaklıkta, \% 60-65 nem ve 16:8 (A:K) fotoperiyot koşullarının sağlandığı iklim odalarında ve popülasyonların birbirleriyle bulaşmalarını engellemek amaciyla içerisinde su dolu küvetler bulunan kafesler içerisinde yetiştirilmiştir.

\section{Çizelge 1- Elma bahçelerinden toplanan Neoseiulus californicus popülasyonları}

Table 1-Neoseiulus californicus populations collected from apple orchards

\begin{tabular}{ccc}
\hline Örneğin toplandiğ yer & Tarih & Bitki \\
\hline Eğirdir & $27-06-2012$ & Elma \\
Eyüpler & $27-06-2012$ & Elma \\
Gelendost & $27-06-2012$ & Elma \\
Hassas & $14-07-2008$ & Elma \\
\hline
\end{tabular}

\subsection{Biyoassay çalışmaları}

\subsubsection{Toksisite testi}

Milbemectin ile yapılan biyoassay çalışmaların tamamında 0-24 saatlik $N$. californicus larvaları kullanılmıştır. Aynı dönem avcı akar larvalarını elde etmek amacıyla, tabanı ıslatılmış pamukla kaplı $9 \mathrm{~cm}$ çapındaki petriler üzerinde hazırlanan barbunya yaprak diskleri üzerine 15 adet ergin avcı akar dişisi aktarılmıştır. 15 adet hazırlanan petrilerden 24 saat sonra birakilan yumurtalar temiz petrilere aktarılmıştır. Yumurtalar açıldıktan sonra aynı dönemdeki avcı akar larvaları denemelerde kullanılmıştır. $\mathrm{Bu}$ yöntemde seçilen ilaçlar saf su içinde çözdürülerek uygun dozlar hazırlanmıştır. Hazırlanan ilk dozdan itibaren ilaç konsantrasyonları $\% 50$ seyreltilerek denemeler 1 kontrol+7 doz, 3 tekerrür olacak şekilde kurulmuştur. Nem sağlamak amacıyla ıslatılmış pamukla kaplı $9 \mathrm{~cm}$ çapındaki petriler üzerinde yaprak diskler hazırlanmıştır. Yaprak disk üzerine 25 adet 0-24 saatlik avcı akar larvaları binoküler altında yumuşak uçlu firça yardımıyla aktarılmıştır. Petrilere ilaçlama kulesinde $1 \mathrm{~atm}$ basınç altında yaprak üzerine $2 \mathrm{~mL}$ olacak 
şekilde ilaç püskürtülmüştür. Kontrole sadece saf su uygulanmıştır. Ayrıca yaprak disk üzerine av olarak kullanılmak üzere T. urticae'nin tüm yaşam dönemlerini içeren bireyler aktarılmıştır. Ölü-canlı sayımları 7. günde yapılmıştır. Elde edilen verilerden yararlanarak farklı avcı akar popülasyonlarının $\mathrm{LC}_{50}$ değerleri POLO bilgisayar paket programında (LeOra Software 1994) hesaplanmıştır. Avcı akar popülasyonlarının belirlenen $\mathrm{LC}_{50}$ değerlerinin hassas popülasyonun $\mathrm{LC}_{50}$ değerine oranlanması ile direnç katları bulunmuştur.

\subsubsection{Sinerjist + ilaç çalışmaları}

Sinerjistlerin ilaçlar üzerindeki etkilerini belirlemek amaciyla monooksigenaz enzim inhibitörü piperonyl butoxide (PBO) (2000 $\mu \mathrm{L} \mathrm{L}^{-1}$ ) (Van Leeuwen et al 2004), esteraz enzim inhibitörü S-BenzylO,O-diisopropyl phosphorothioate (IBP) $(200 \mu \mathrm{L}$ $\left.\mathrm{L}^{-1}\right)$ (Kim et al 2004) ve GST enzim inhibitörü diethylmaleate (DEM) $\left(2000 \mu \mathrm{L} \mathrm{L}^{-1}\right)$ (Van Leeuwen et al 2004) sinerjistleri kullanılmıştır. Sinerjist+ilaç çalışmalarında avcı akarın 0-24 saatlik larvaları kullanılmıştır. Denemeler biyoassay çalışmalarda anlatıldığ 1 gibi 1 kontrol +7 doz ve 3 tekerrür olarak kurulmuştur. Sinerjistler 1:1 oranında aseton:saf su içerisinde çözülmüştür. Hazırlanan sinerjist çözeltileri ilaçlama kulesinde petrilere $1 \mathrm{~atm}$ basınç altında $1 \mathrm{ml}$ olarak püskürtülmüştür. Ayrıca yaprak disk üzerine av olarak kullanılmak üzere $T$. urticae aktarılmıştır. İçerisinde avcı akar bulunan petriler 24 saat boyunca $26 \pm 1{ }^{\circ} \mathrm{C}$ sicaklikta \% 60-65 nem ve 16:8 fotoperiyot koşullarının sağlandığı iklim odalarında bırakılmıştır. Sinerjist uygulamasından 24 saat sonra hazırlanan ilaç solüsyonları ile ilaçlama yapılmıştır. Kontrolde sadece sinerjist uygulanmıştır. Ölü-canlı sayımları 7 . günde yapılmıştır. Elde edilen verilerden yararlanarak farklı akar popülasyonlarının $\mathrm{LC}_{50}$, değerleri POLO bilgisayar paket programında hesaplanmıştır.

Sinerjistik etki oran $1=$ Sinerjistsiz $\mathrm{LC}_{50} /$ Sinerjistli $\mathrm{LC}_{50}$

\subsection{Biyokimyasal çalışmalar}

\subsubsection{Poliakrilamid jel elektroforez (PAGE) ile esteraz enziminin incelenmesi}

Elektroforez çalışmalarında Goka \& Takafuji (1992), Ay \& Gürkan (2005)'nın yöntemleri uyarlanarak kullanılmıştır. Elektroforez işlemi mini kasetli sistemde (Bio-Rad) \% 7.5'luk ayırıcı ve \% 3.5'luk yükleyici jel içeren kesikli doğal elektroforez metodu kullanılmıştır. 5 adet ergin dişi birey $50 \mu \mathrm{l}$ homojenizasyon tamponunda (\% 0.1 Triton X-100 içeren \% 32'lik sukroz) içerisinde plastik ezici ile homojenize edilmiştir. Polimerizasyondan sonra her bir jel hücresine $10 \mu 1$ homojenat yüklenmiştir. Elektroforezde koşturma işlemi $150 \mathrm{~V}$ 'da yaklaşık 1.5 saat'de tamamlanmıştır. $0.2 \mathrm{M}$ fosfat buffer (pH 6.5 ve \% 1 aseton içeriyor) ile \% 0.02 lik a-naphthyl asetat subsrat solüsyonu hazırlanmıştır. Jel bu çözeltide esteraz enzimi inkübasyonu için $30 \mathrm{dk}$. bekletilmiştir. \% 0.02 'lik a-naphthyl asetat solüsyonu ile $\% 0.4$ oranında fast blue BB salt boya solüsyonu hazırlanmış ve jel bu çözeltide 1 saat boyanmıştır. Boyama işlemi bittikten sonra jel \% 7'lik asetik asit çözeltisi içerisine alınmış ve 24 saat sonra görüntüleme cihazında fotoğrafı çekilmiştir.

\subsubsection{Neoseiulus californicus'un toplam esteraz enziminin kinetik olarak belirlenmesi}

Esteraz aktivitesinin kinetik olarak belirlenmesinde substrat olarak $\alpha$-naphtyl acetate ve Stumpf \& Nauen (2002)'in geliştirdikleri yöntem kullanılmıştır. 20 adet ergin dişi $100 \mu \mathrm{l}$ sodyum fosfat buffer (0.1M, pH 7.5) (\% 0.1 Triton X-100 içeren) içinde homojenize edilmiştir. Bu homojenat $10000 \mathrm{~g},+4{ }^{\circ} \mathrm{C}$ 'de ve $5 \mathrm{dk}$ santrifüj edildikten sonra enzim kaynağı olarak kullanılmışır. Enzim kaynağı olarak kullanılan supernatant 10 kez seyreltilmiştir. Mikroplakanın hücrelerine $25 \mathrm{~mL}$ supernatant +25 $\mathrm{mL}$ fosfat buffer $(0.2 \mathrm{M}$, pH: 6) konulmuştur. Çalışma hücrelere $200 \mu \mathrm{L}$ substrat solüsyonunun eklenmesiyle başlatılmıştır. Substrat solüsyonu 30 mg fast blue RR tuzunun $50 \mathrm{~mL} 0.2 \mathrm{M}$ sodyum fosfat buffer'da çözülmesi ve bu karışıma $500 \mu \mathrm{L}$ $100 \mathrm{Mm} \alpha$-naphtyl acetate'1n eklenmesiyle elde 
edilmiştir. Enzim aktivitesi $23^{\circ} \mathrm{C}, 450 \mathrm{~nm}$ 'de $10 \mathrm{dk}$ süreyle okunmuştur.

\subsubsection{Neoseiulus californicus'un glutathion S-transferaz (GST) enziminin kinetik olarak incelenmesi}

GST enziminin kinetik olarak belirlenmesinde Stumpf \&Nauen (2002)'in geliştirdikleri yöntem kullanılmıştır. 30 ergin dişi $300 \mu \mathrm{L}$ Tris $\mathrm{HCl}$ buffer (0.05M, pH:7.5) içinde homojenize edilmiştir. Supernatant $10000 \mathrm{~g},+4{ }^{\circ} \mathrm{C}$ 'de $5 \mathrm{dk}$ santrifüj edilmiştir. $100 \mu \mathrm{L}$ supernatant, $100 \mu \mathrm{L}$ 1-chloro2,4-dinitrobenzene (CDNB) ve $100 \mu \mathrm{L}$ reduced glutathione (GSH)'dan oluşan toplam hacim mikroplaka hücrelerine konulmuştur. CDNB \% 0.1 ethanolde hazırlanmış ve final konsantrasyonda hücrelerde $0.4 \mathrm{mM}$ CDNB bulunmuştur. GSH, Tris $\mathrm{HCl}$ tamponda hazırlanmış ve final konsantrasyonda hücrelerde $4 \mathrm{mM} \mathrm{GSH}$ bulunmuştur. Absorbanstaki değişim $340 \mathrm{~nm}, 25^{\circ} \mathrm{C}$ 'de ve $5 \mathrm{dk}$ 'da okunmuştur.

\subsubsection{Neoseiulus californicus'un monoksigenaz (P450) enziminin kinetik olarak incelenmesi}

Sitokrom P450 monooksigenaz enziminin belirlenmesinde substrat olarak $p$-nitroanisole (PNOD) ve Rose et al (1995) yöntemi uyarlanarak kullanılmıştır. 50 adet dişi birey $100 \mathrm{~mL}$ homojenizasyon bufferında $(0.05 \mathrm{M}$ Tris- $\mathrm{HCl}+\%$ $1.15 \mathrm{KCl}+1 \mathrm{mM}$ EDTA, $\mathrm{pH}:$ 7.7) plastik ezici ile ezilerek $+4{ }^{\circ} \mathrm{C} 10000 \mathrm{~g}$ 'de $20 \mathrm{dk}$ santrifüj edilmiştir. Mikroplaka hücrelerine $45 \mathrm{~mL}$ homojenizasyon buffer $+45 \mathrm{~mL}$ supernatant $+100 \mathrm{~mL} 2 \mathrm{mM}$ PNOD eklenerek karışım $30{ }^{\circ} \mathrm{C}$ 'de $5 \mathrm{dk}$ inkübe edilmiştir. Reaksiyon mikroplaka hücrelerine $10 \mathrm{~mL} 9.6 \mathrm{mM}$ NADPH eklenerek başlatılmıştır. P450 enzim aktivitesi Versamax kinetic microplate reader'da (Molecular Devices) $405 \mathrm{~nm} 30^{\circ} \mathrm{C}^{\prime} \mathrm{de} 15 \mathrm{dk}$ süreyle ölçülmüştür.

\subsubsection{Neoseiulus californicus'un asetilkolinesteraz (AChE) enziminin kinetik olarak incelenmesi}

Asetilkolinesteraz belirlenmesinde Stumpf et al (2001) yöntemi uyarlanarak kullanılmıştır. $N$. californicus 'un 50 ergin dişisi eppendorf tüp içinde bulunan $500 \mathrm{~mL} \% 0.1$ Trion X-100 içeren fosfat buffer (0.1 M pH: 7.5) içinde plastik ezici ile homojenize edilmiştir. Buz içinde $20 \mathrm{dk}$ dokuların çözülmesi beklendikten sonra, homojenat 10000 $\mathrm{g}, 4{ }^{\circ} \mathrm{C}$ 'de ve $5 \mathrm{dk}$ santrifüj edilerek elde edilen supernant enzim kaynağı olarak kullanılmıştır. AChE aktivitesini ölçmek için mikroplaka hücrelerine $100 \mathrm{~mL}$ acetylcholine iodide (ATChI), $100 \mathrm{~mL}$ 5.5-dithiobis (2-nitrobenzoic acid) (DTNB) ve $100 \mathrm{~mL}$ enzim solüsyonu konmuştur. 300 mL'lik final konsantrasyonunda her bir maddenin miktarı $0.5 \mathrm{mM}$ olmuştur. AChE aktivitesi kinetik mikroplaka okuyucuda $23{ }^{\circ} \mathrm{C}$ de $412 \mathrm{~nm}$ 'de 20 dakikada ölçülmüştür.

Biyokimyasal çalışmalarda, kontrol hücreleri ise homojenatsız olarak okunmuştur. Enzim okumaları en az üç tekerrürlü olacak şekilde yapılmıştır. Tüm enzim aktiviteleri Softmax PRO software programında analiz edilmiş ve sonuçlar mOD $\mathrm{min}^{-1} \mathrm{mg}^{-1}$ olarak verilmiştir. Örneklerin toplam protein miktarlarının belirlenmesinde Bradford (1976)'un total protein tayin yöntemi kullanılmış ve Bovine Serum Albumine (BSA) standart olarak alınmıştır. Enzim sonuçlarından elde edilen veriler tek yönlü varyans analizi tekniği ile (OneWay ANOWA) analiz edilmiş ve popülasyonlar arasındaki farklılıkların belirlenmesinde Tukey testi kullanılmıştır (Winer et al 1991).

\section{Bulgular ve Tartışma}

$\mathrm{Bu}$ çalışmada zararlı kırmızı örümceklerin önemli ve etkili bir avcısı olan $N$. californicus'un elma bahçelerinden toplanan popülâsyonlarının milbemectin'e karşı direnç düzeyleri ve direnç mekanizmaları biyoassay ve biyokimyasal yöntemlerle belirlenmiştir.

\subsection{Biyoassay sonuçları}

\subsubsection{Toksisite sonuçları}

Isparta ili Eğirdir ve Gelendost ilçelerindeki elma bahçelerinden toplanan N. californicus popülâsyonlarının milbemectin'e karşı duyarlılık düzeyleri Çizelge 2'de verilmiştir. 
Çizelge 2-Neoseiulus californicus popülasyonlarının milbemectin'e karşı belirlenen $\mathrm{LC}_{50}$ değerleri ve direnç oranları

Table 2- Resistance rations and $L C_{50}$ levels determined from Neoseiulus californicus populations to milbemectin

\begin{tabular}{|c|c|c|c|c|}
\hline Popülasyon & $n^{*}$ & Eğgim $+s e$ & $\begin{array}{c}L C_{50}\left(m g \text { a.i } l^{-1}\right) \\
(\% 95 C L)\end{array}$ & $R^{* *}$ \\
\hline Eğirdir & 600 & $1.35 \pm 0.12$ & $\begin{array}{c}2.45 \\
1.87-3.13\end{array}$ & 7.20 \\
\hline Eyüpler & 600 & $1.42 \pm 0.11$ & $\begin{array}{c}2.22 \\
1.81-2.71\end{array}$ & 6.52 \\
\hline Gelendost & 600 & $1.36 \pm 0.12$ & $\begin{array}{c}2.50 \\
1.94-3.15\end{array}$ & 7.35 \\
\hline $\begin{array}{c}\text { Hassas } \\
\text { popülasyon }\end{array}$ & 600 & $1.98 \pm 0.21$ & $0.21-0.46$ & - \\
\hline
\end{tabular}

*, Denemede kullanılan birey sayı; ${ }^{* *}$, Direnç oranı

N. californicus popülâsyonlarında milbemectin'e karşı en yüksek direnç oranı 7.35 kat ile Gelendost popülâsyonunda belirlenmiştir. Eğirdir popülâsyonunda milbemectin'e karşı 7.20 kat ve Eyüpler popülâsyonunda ise 6.52 kat direnç belirlenmiştir. Hassas popülâsyonla karşılaştırıldığında tarla popülâsyonlarının tamamı milbemectin'e karş1 LC $_{50}$ değerlerine göre dirençli bulunmuştur. Eğirdir, Eyüpler ve Gelendost popülâsyonlarında $7.20,6.52$ ve 7.35 kat direnç belirlenmiştir. Sato et al (2005) 342 kat abamectin dirençli T. urticae popülasyonunda milbemectin'e karş1 16.3 kat çapraz direnç geliştiğini belirlemişlerdir. Suh et al (2006) sera ve elma bahçesinden toplanan T. urticae popülasyonlarında fenpyroximate ve pyridaben direnç oranlarını saptamışlardır. Sökeli et al (2007) Isparta ili ve çevresindeki elma üretimi yapılan alanlardan toplanan T. urticae popülasyonlarında propargite, chlorpyrifos ve abamectin için sırasıyla $<1.0-1.046$, 2.341-40.206 ve $<1.0-1.387$ kat direnç belirlemiştir. Bonafos et al (2007) bağ alanlarından topladıkları avc1 akarlar $T$. pyri ve $A$. andersoni popülasyonlarının deltamethrin, lamda-cyhalothrin ve chlorpyrifosethly'e karşı orta düzeyden yüksek düzeye kadar değişen oranlarda dirençli bulmuşlardır. Yorulmaz et al (2010) Isparta elma bahçelerinden topladıkları 13 adet $T$. urticae popülâsyonunda cyhexatin'e karşı 1.24-
3.36 kat, propargite karşı ise 1.23-3.18 kat arsında değişen direnç tespit etmişlerdir. Mugo et al (2011) chlorpyrifosa karşı Euseius kenyae (Swirski \& Ragusa) (Acari: Phytoseiidae)'nun popülâsyonlarında 1-10 kat arasında değişen düzeylerde direnç bulmuşlardır. Tirello et al (2012) bağ alanları ve elma bahçelerinden toplanan dört fakl1 Kampimodromus aberrans (Oudemans) (Acari: Phytoseiidae) popülâsyonlarında 1.85-6.83 arasında değişen katlarda chlorpyrifos direnci belirlemişlerdir. Yorulmaz \& Ay (2012) Isparta ili elma bahçelerinden topladıkları $N$. californicus'un 8 popülasyonunda spiromesifen'e karş1 4.35-7.61 kat; hexythiazox'a karşı 3.75-8.01 kat, ve spirodiclofen'e karş1 5.07-8.60 kat direnç belirlemişlerdir. Literatürde de yapılan çalışma ile benzer şekilde bazı avcı akarların tarla koşullarında bazı pestisitlere karşı direnç geliştirebildiği belirtilmektedir. Milbemectin elma bahçelerinde iki noktalı kırmızı örümcek ve Avrupa kırmızı örümceğine karşı 14.06.2012 tarihinde ruhsat almış ve bu tarihten sonra elma bahçelerinde uygulanmaya başlanmıştır. Bunun yanı sıra son birkaç yıla kadar Isparta ilindeki elma bahçelerinde kırmızı örümcek mücadelesi için abamectin kullanılmaktadır (Sökeli et al 2007). Özellikle N. californicus'un tarla popülâsyonlarında gelişen milbectin direncinin önceki y1llarda kullanılan abamectin ile bağlantılı olduğu düşünülmektedir. Çünkü abamectin ile milbemectin arasında çapraz direnç gelişimi bulunmaktadır (Sato et al 2005).

\subsubsection{Sinerjist + ilaç sonuçlart}

N. californicus popülâsyonlarında milbemectin $+\mathrm{PBO}$, milbemectin+IBP ve milbemectin+DEM sinerjistlerinin birlikte uygulanması sonucu belirlenen sinerjistik etki oranları Çizelge 3'de verilmiştir.

Milbemectin+PBO'nun birlikte uygulanmas sonucunda Eğiridir popülasyonunda $<1$ kat, Eyüpler popülasyonunda 1.59 kat ve Gelendost popülasyonunda ise 1.85 kat sinerjistik etki oranları belirlenmiştir. Milbemectin+IBP'un birlikte uygulanması sonucunda tüm popülâsyonlarda belirlenen sinerjistik etki oranları birbirine yakın bulunmuştur (sırasıyla Eğiridir, Eyüpler ve Gelendost popülâsyonları için; 1.81, 1.86 ve 1.82 kat). DEM sinerjistinin milbemectin ile 
Çizelge 3- Neoseiulus californicus popülasyonlarında milbemectin ve milbemectin+ sinerjistlerin $\mathrm{LC}_{50}$ değerleri ve sinerjistik etki oranları

Table 3- $L C_{50}$ levels and synergistic effect rates of milbemectin and milbemectin+synergist in Neoseiulus californicus populations

\begin{tabular}{|c|c|c|c|c|}
\hline Popülasyon & $n^{*}$ & Ĕgim $\pm s e$ & $\begin{array}{c}L C_{50}\left(\text { mg a.i } l^{-1}\right) \\
(\% 95 C L) \\
\end{array}$ & $S R^{* *}$ \\
\hline $\begin{array}{c}\text { Ĕ̆irdir } \\
\text { (Sinerjistsiz) }\end{array}$ & 600 & $1.35 \pm 0.12$ & $\begin{array}{c}2.45 \\
1.87-3.13\end{array}$ & - \\
\hline Milbemectin $+\mathrm{PBO}$ & 600 & $1.87 \pm 0.15$ & $\begin{array}{c}2.47 \\
1.92-2.84\end{array}$ & 0.99 \\
\hline Milbemectin +IBP & 600 & $1.34 \pm 0.16$ & $\begin{array}{c}1.35 \\
1.05-1.64\end{array}$ & 1.81 \\
\hline Milbemectin +DEM & 600 & $1.38 \pm 0.13$ & $\begin{array}{c}1.31 \\
1.01-1.66\end{array}$ & 1.87 \\
\hline Eyüpler (Sinerjistsiz) & 600 & $1.42 \pm 0.11$ & $\begin{array}{c}2.22 \\
1.81-2.71\end{array}$ & - \\
\hline Milbemectin $+\mathrm{PBO}$ & 600 & $1.80 \pm 0.15$ & $\begin{array}{c}1.39 \\
1.12-1.69\end{array}$ & 1.59 \\
\hline Milbemectin +IBP & 600 & $1.46 \pm 0.14$ & $\begin{array}{c}1.19 \\
0.90-1.51\end{array}$ & 1.86 \\
\hline Milbemectin +DEM & 600 & $1.24 \pm 0.10$ & $\begin{array}{c}1.46 \\
1.03-2.13 \\
\end{array}$ & 1.52 \\
\hline Gelendost (Sinerjistsiz) & 600 & $1.36 \pm 0.12$ & $\begin{array}{c}2.50 \\
1.94-3.15\end{array}$ & - \\
\hline Milbemectin + PBO & 600 & $1.41 \pm 0.14$ & $\begin{array}{c}1.35 \\
1.02-1.72\end{array}$ & 1.85 \\
\hline Milbemectin +IBP & 600 & $1.28 \pm 0.13$ & $\begin{array}{c}1.37 \\
1.03-1.77\end{array}$ & 1.82 \\
\hline Milbemectin +DEM & 600 & $1.32 \pm 0.10$ & $\begin{array}{c}1.11 \\
0.90-1.10\end{array}$ & 2.25 \\
\hline
\end{tabular}

*, Birey sayısı; **, Sinerjistik etki oranı

birlikte uygulanmas1 sonucunda ise Gelendost popülâsyonunda 2.25 kat ile en yüksek sinerjistik etki oranı bulunmuştur. Eyüpler popülâsyonunda 1.52 kat ile en düşük sinerjistik etki oranı belirlenirken, Eğiridir popülasyonunda ise 1.87 kat etki bulunmuştur.

\subsection{Biyokimyasal sonuçlar}

Biyokimyasal çalışmalar içerisinde $N$. californicus popülâsyonlarının esteraz enzimleri hem elektroforetik hem de kinetik olarak incelenmiştir. Ayrıca N. californicus popülâsyonlarının GST, sitokrom P450 ve AChE enzim aktiviteleri de kinetik olarak belirlenmiştir.
3.2.1. Esteraz, glutathion s-transferaz (gst), sitokrom p450 monooksigenaz ve asetilkolinesteraz (ache) enzim aktivitesi sonuçları

N. californicus'un hassas Eğirdir, Eyüpler ve Gelendost popülasyonlarının esteraz, GST, P450 ve AChE enzim seviyeleri Çizelge 4'de verilmiştir.

Esteraz enzimi Eğirdir popülasyonunda 11.64 $\mathrm{mOD} \mathrm{min}^{-1} \mathrm{mg}^{-1}$ protein değeriyle en yüksek olarak belirlenmiştir. Gelendost popülâsyonunda 10.29

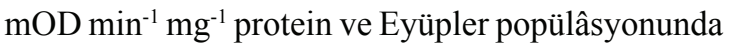
ise $9.28 \mathrm{mOD} \mathrm{min}^{-1} \mathrm{mg}^{-1}$ protein olarak belirlenmiştir. Tarla popülâsyonlarının tamamında esteraz enzim seviyesi hassas popülâsyona göre 
Çizelge 4- Neoseiulus californicus popülasyonlarının esteraz, GST, P450 ve AChE enzim aktiviteleri $(\mathbf{P}<\mathbf{0 . 0 5})$

Table 4- Esterase, GST, P450 and AChE enzyme activities of Neoseiulus californicus populations $(P<0.05)$

\begin{tabular}{|c|c|c|c|c|c|c|c|c|}
\hline & & Esteraz & & $G S T$ & & P450 & & AChE \\
\hline Popülasyon & $N^{*}$ & $\begin{array}{c}m O D^{-1} \min ^{-1} m g \\
\text { protein }\end{array}$ & $N^{*}$ & $\begin{array}{c}m O D^{-1} \min ^{-1} m g \\
\text { protein }\end{array}$ & $N^{*}$ & $\begin{array}{c}m O D^{-1} \min ^{-1} m g \\
\text { protein }\end{array}$ & $N^{*}$ & $\begin{array}{c}m O D^{-1} \mathrm{~min}^{-1} \mathrm{mg} \\
\text { protein }\end{array}$ \\
\hline Eğirdir & 4 & $11.64 \mathrm{~A}^{* *}$ & 4 & $3.70 \mathrm{~A}^{* *}$ & 4 & $0.02 \mathrm{~B}^{* *}$ & 4 & $0.01 \mathrm{~A}^{* *}$ \\
\hline Eyüpler & 4 & $9.28 \mathrm{~A}^{* *}$ & 4 & $3.82 \mathrm{~A}^{* *}$ & 4 & $0.03 \mathrm{~B}^{* *}$ & 4 & $0.01 \mathrm{~A}^{* *}$ \\
\hline Gelendost & 4 & $10.29 \mathrm{~A}^{* *}$ & 4 & $3.12 \mathrm{~A}^{* *}$ & 4 & $0.05 \mathrm{~A}^{* *}$ & 4 & $0.02 \mathrm{~A}^{* *}$ \\
\hline $\begin{array}{c}\text { Hassas } \\
\text { popülasyon }\end{array}$ & 4 & $8.86 \mathrm{~B}^{* * *}$ & 4 & $2.11 \mathrm{~B}^{* * *}$ & 4 & $0.03 \mathrm{~B}^{* *}$ & 4 & $0.02 \mathrm{~A}^{* *}$ \\
\hline
\end{tabular}

${ }^{*}, \mathrm{~N}$ : tekerrür sayısı

**, Sütunlar yukarıdan aşağıya incelendiğinde aynı harfi içeren ortalamalar istatistiksel olarak önemli değildir $(\mathrm{P}<0.05)$

yüksek bulunmuş ve istatistiki olarak faklı grupları oluşturmuşlardır $(\mathrm{P}<0.05)$ (Çizelge 4). GST enzimi

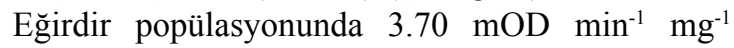
protein değeriyle en yüksek oranda belirlenirken,

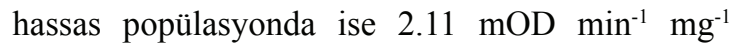
protein değeriyle en düşük seviyede belirlenmiştir. GST enzimi bakımından tarla popülasyonlarının tamamı ile hassas popülasyon istatistiki olarak birbirlerinden farklı bulunmuşlardır $\quad(\mathrm{P}<0.05)$ (Çizelge 4). Eğirdir ve Eyüpler popülasyonlarında P450 enzim seviyesi hassas popülasyonla benzer bulunmuş ve bu üç popülasyon istatistiki olarak aynı grup içerisinde yer almışlardır. P450 enzimi

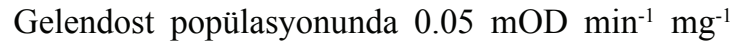
protein değeriyle en yüksek seviyede belirlenerek istatistiki olarak diğerlerinden farklı bir grubu oluşturmuştur (Çizelge 4). N. californicus'un tüm popülâsyonlarında $\mathrm{AChE}$ enzim seviyesi birbirlerine benzer bulunarak aynı grup içerisinde yer almışlardır $(\mathrm{P}<0.05)$.

$N$. californicus'un Eğirdir, Eyüpler ve Gelendost popülasyonlarında milbemectin+PBO'nun birlikte uygulanması sonucunda sirasiyla $<1$ kat, 1.59 kat ve 1.85 kat sinerjistik etki belirlenmiştir. Milbemectin'e karşı 7.35 kat ile en yüksek direnç oranına sahip Gelendost popülâsyonunda P450 monoksigenaz enzim inhibitörü PBO sinerjisti için 1.85 kat ile en yüksek sinerjistik etki belirlenmiştir. Bunun yanı sıra Gelendost popülâsyonunda 0.05
$\mathrm{mOD}$ min $^{-1} \mathrm{mg}^{-1}$ protein değeri ile en yüksek P450 monooksigenaz enzim aktivitesi de bulunmuştur. Eğirdir popülâsyonunda PBO ile yapılan çalışmalar sonucunda $<1$ sinerjistik etki oranı belirlenmiştir. $\mathrm{Bu}$ popülâsyonda $\mathrm{P} 450$ monoksigenaz enzimi hassas popülâsyonla benzer bulunmuştur. Eyüpler popülâsyonunda ise $\mathrm{PBO}$ için 1.59 kat sinerjistik etki belirlenmiş, fakat P450 enzim seviyesi hassas popülâsyonla benzer bulunmuştur. P450 enzimi ve PBO sinerjisti birlikte düşünüldüğünde Gelendost popülâsyonunda milbemectin'e karşı gelişen dirençte P450 monoksigenaz enziminin etkisi olduğu düşünülmektedir. Sato et al (2001) monooksigenaz inhibitörleri olan piperonyl butoxide ve 2-propynyl 2,3,6-trichlorophenyl'in methidathion dirençli $A$. womersleyi'de yüksek derecede sinerjistik etki gösterdiğini ve oksidatif metabolizmasının arttığını ortaya koymuşlardır. Kim et al (2006) 240 kat pyridaben dirençli $T$. urticae'de fenpyroximate için 373 kat, acrinathrin için 329 kat, benzoximate için 84 kat direnç tespit belirledikleri çalışmada PBO'nun pyridaben direnci üzerinde büyük etkisi olduğunu bulmuşlardır. Sato et al (2006) 177 kat methidathiona dirençli ve hassas $A$. womersleyi'de monoksigenaz aktivitesinin dirençli popülâsyonda hassas popülasyona göre 3.60 kat arttığını belirlemişlerdir.

Milbemectin+IBP ile yapılan çalışmalar sonucunda $N$. californicus'un tüm tarla 
popülasyonlarında sinerjistik etki oranları birbirine yakın bulunmuştur (1.81-1.86 kat). Esteraz enzim inhibitörü IBP sinerjisti ile yapılan çalışmalar popülâsyonlarda belirlenen esteraz enzim seviyelerini de desteklemektedir. Çünkü Eğirdir, Eyüpler ve Gelendost popülâsyonlarında belirlenen esteraz enzim miktarları hassas popülâsyonda belirlenen enzim miktarlarına göre daha yüksek olmuş ve istatistikî olarak farklı bulunmuştur $(\mathrm{P}<0.05)$. Elektroforez çalışmaları sonucu özellikle Eğirdir ve Gelendost popülâsyonlarından elde edilen esteraz bantlarının hassas popülâsyondan elde edilen bantlara göre daha kalın olduğu belirlenmiştir (Şekil 1).

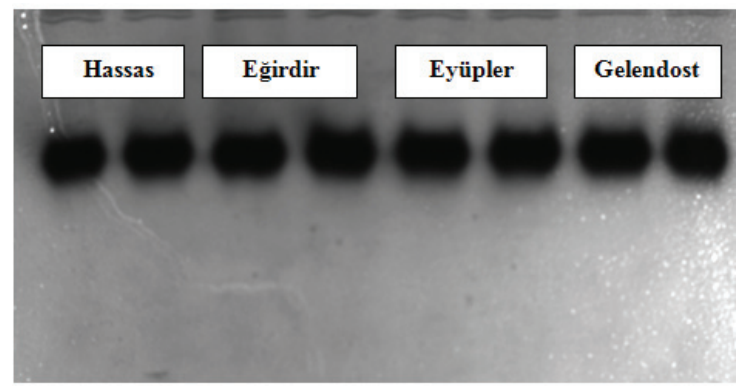

Şekil 1- Neoseiulus californicus popülasyonlarının esteraz izozimleri

Figure 1- Esterase isozymes of Neoseiulus californicus populations

$\mathrm{Bu}$ sonuçlar göz önüne alındığında $N$. californicus'un tüm tarla popülâsyonlarında milbemectin'e karşı gelişen dirençte esteraz enziminin rol oynadığı düşünülmektedir. Booth et al (2007) tarla ve laboratuvar koşullarında, lambdacyhalothrin ve dimethoate'nin Rhopalosiphon padi (L.) (Hemiptera: Aphidoidea) ve afitin predatörü olan Micromus tasmaniae Walker (Neuroptera: Hcmerobidaee) üzerine etkilerini araştırdıkları çalışmada kolinesteraz enzimi dimethoate direncini etkilerken; GST enziminin lambda-cyhalothrin ve dimethoate üzerine etkisi olmadığı belirlemişlerdir. Sayyed et al (2010) 896 kat deltamethrin dirençli Chrysoperla carnae (Neuroptera: Chrysopidae) popülâsyonunda esteraz ve monoksigenaz enzim seviyelerinin arttığını belirlemişlerdir.
GST enzim inhibitörü DEM sinerjisti ile yapılan çalışmalar sonucunda milbemectin'e karşı 7.35 kat ile en yüksek direnç oranına sahip olan Gelendost popülâsyonunda 2.25 kat ile en yüksek sinerjistik etki belirlenmiştir. Eğirdir ve Eyüpler popülâsyonlarında da 1.87 ve 1.52 kat ile DEM sinerjisti için yüksek sinerjistik etkiler bulunmuştur. Bunun yanı sıra Eğirdir, Eyüpler ve Gelendost popülasyonlarının tamamında GST enzim seviyesi hassas popülasyona göre yüksek bulunmuş ve istatistiki olarak farklı gruplarla ifade edilmişlerdir $(\mathrm{P}<0.05)$. Fournier et al (1987) Phytoseiulus persimilis (Acari: Phytoseiidae)'in demethidathion direnci üzerinde yalnızca GST enziminin etkili olduğunu bulmuşlardır. Pottelberge et al (2009) 274 kat spirodiclofen dirençli T. urticae popülâsyonunda P450 monoksigenaz, esteraz ve GST enzimlerinin direnç gelişiminde rol oynadığını belirlemişlerdir. Yorulmaz \& Ay (2009) seleksiyon sonucu 35.05 kat abamectin direnci geliştirilen $T$. urticae popülasyonunda GST ve P450 monooksigenaz enzimlerinin etkili olduğunu belirlemişlerdir.

Neoseiulus californicus'un Eğirdir, Eyüpler ve Gelendost popülasyonlarında belirlenen AChE enzim seviyeleri hassas popülasyonda belirlenen AChE enzim seviyesi arasında istatistiki olarak bir farklılık bulunmamıştır. $\mathrm{Bu}$ durumda avc1 akarın tarla popülâsyonlarında gelişen milbemectin direnci üzerine AChE enziminin bir etkisi olmadığ söylenebilir. Ancak kesin bir ifade için AChE enzim inhibitörü olan sinerjistlerle çalışma yapılmasının faydalı olacağ 1 düşünülmektedir. Anber and Overmeer (1988) A. andersoni'de substrat olarak acetylthiocholine kullanarak S ve A irklarında 0.71 ve 0.35 kat asetilkolinesteraz enzimi belirlemişlerdir. Kumral et al (2011) P. ulmi ve avcis1 Stethorus gilvifrons (Mulsant) (Coleoptera: Coccinellidae)'da parathion-methyl direnci, karboksilesteraz enzim seviyesi ve AChE hassasiyetini benzer bulmuşlar ve Stethorus gilvifrons'un tarla koşullarında ilaçlara karşı direnç geliştirebileceği belirtilmiştir.

\subsubsection{Poliakrilamid jel elektroforez sonuçları}

$N$. californicus popülâsyonlarının esteraz enzimleri poliakrilamid jel elektroforez yöntemiyle 
belirlenmiş ve bantlar Şekil 1'de verilmiştir. $N$. californicus'un tüm popülasyonarında esteraz enzimleri tek banttan oluştuğu belirlenmiştir. Hassas popülâsyona ait bantlara Eyüpler popülasyonuna ait bantlar benzerlik göstermiştir. Eğirdir ve Gelendost popülâsyonuna ait bantların kalınlıkları ise hassas popülasyona ait bant kalınlıklarından biraz daha yoğun olduğu gözlemlenmiştir.

\section{Sonuçlar}

Sonuç olarak, bu çalışmada $N$. californicus'un tarla popülâsyonlarının milbemectin'e karşı direnç gelişimleri biyoassay ve biyokimyasal yöntemlerle incelenerek direnç mekanizmaları belirlenmeye çalışılmıştır. Özellikle kırmızı örümcek mücadelesinde uzun y1llardan beri abamectin kullanılan elma bahçelerinde milbemectin'e karşı belirlenen dirençte abamectin'in sorumlu olduğu düşünülmektedir. Çünkü abamectin ve milbemectin aynı grup içerisinde yer alan ve aralarında çapraz direnç gelişimi belirlenen akarisitlerdir. Bu nedenle milbemectin'in de uzun süre kullanımlarında abamectin benzeri zararlı ve doğal düşman popülâsyonları üzerinde direnç gelişimine neden olacağı düşünülmektedir. $\mathrm{Bu}$ tür çalışmaların yapılarak olası sonuçların ortaya konması ileride entegre mücadele programları içerisinde hem milbemectin dirençli zararlıların mücadelesinde hem de dirençli doğal düşmanların kullanımında fayda sağlayacaktır. Avcı akarın tarla popülâsyonlarında milbemectin`e karşı direnç gelişiminden tek bir enzim aktivitesinin sorumlu olmadiğı, esteraz, P450 monooksigenaz ve GST enzimlerinin değişik oranlarda direnç gelişimine katıldığı düşünülmektedir. İlaçların doğal düşmanlar üzerindeki yan etkilerinin yanı sıra predatör ve parazitoidlerin bazı kimyasallara karşı direnç kazandığı bilinmektedir. Çünkü yoğun ilaç uygulanan alanlarda bulunan doğal düşmanlar hedef olmamalarına rağmen uygulanan kimyasallardan dolaylı olarak etkilenmektedir. Bir şekilde ilaçlara karşı direnç kazanan doğal düşmanların özellikle direnç yönetim programları içerisinde kullanılabileceği düşünülmektedir (Sato et al 2000). Ayrıca yapılan bu çalışma, avcı akar $N$. californicus'da milbemectin direnç mekanizmasının belirlenmesi adına dünyada ve ülkemizde yapılan ilk çalışma olması yönünden de önem kazanmaktadır. Bu tür çalışmalar N. californicus'da ilerde yapılacak olan diğer çalışmalara da altyapı hazırlaması yönünden fayda sağlayacağ 1 düşünülmektedir.

\section{Teşekkür}

$\mathrm{Bu}$ çalışmada elma bahçelerinden toplanan kırmızı örümceklerin teşhisini yapan Prof. Dr. Sultan ÇOBANOĞLU'na teşekkür ederiz. 110-O-631 No 'lu proje ile çalışmayı maddi olarak destekleyen Türkiye Bilimsel ve Teknik Araştırmalar Kurumu (TÜBİTAK-TOVAG)'a teşekkür ederiz.

\section{Kaynaklar}

Anber H A I \& Overmeer W P J (1988). Resistance to organophosphates and carbamates in the predacious mite Amblyseius potentillae (Garman) due to insensitive acetylcholinesterase. Pesticide Biochemistry and Physiology 31(1): 91-98

Ay R \& Gürkan M O (2005). Resistance to bifenthrin and resistance mechanisms of different strains of the twospotted spider mite (Tetranychus urticae Koch) from Turkey. Phytoparasitica 33: 237-244

AugerP,BonafosR, KreiterS\& DelormeR(2005).Agenetic analysis of mancozeb resistance in Typhlodromus pyri (Acari:Phytoseiidae). Experimental and Applied Acarology 37: 83-91

Bloomquist J R (2001). GABA and glutamate receptors as biochemical sites for insecticide action. In: Ishaaya I (ed) Biochemical sites of insecticide action and resistance. Springer, New York, pp: 17-41

Bonafos R, Serrano E, Auger P \& Kreiter S (2007). Resistance to deltamethrin, lambda-cyhalothrin and chlorpyriphos-ethyl in some populations of Typhlodromus pyri Scheuten and Amblyseius andersoni (Chant) (Acari:Phytoseiidae) from vineyards in the south-west of france. Crop Protection 26: $169-172$

Booth L H, Wratten S D \& Kehrli P (2007). Effects of reduced rates of two insecticides on enzyme activity and mortality of an aphid and its lacewing predator. Journal Economic Entomology 100(1): 11-19

Bradford M M (1976). A rapid and sensitiv method for the quantitation of microgram quantities of 
protein utilizing the principle of protein-dye inding. Analytical Biochemistry 72: 248-254

Canlas LJ,Amano H, OchiaiN \& Takeda M(2006). Biology and predation of the japanese strain of Neoseiulus californicus (McGregor)(Acari:Phytoseiidae). System Applied Acarology 11: 141-157

Castagnoli M \& Falchin L (1993). Suitability of Polypphagotarsonemus latus (Banks) (Acari:Tarsonemidae) as prey for Amblyseius californicus (McGregor) (Acarina:Phytoseidae). Redia 77: 273-279

Castagnoli M \& Simoni S (1999). Effect of long-term feeding history on functional and numerical response of Neoseiulus californicus (Acari:Phytoseiidae). Experimental Applied Acarology 23: 217-234

Clark C M, Scott C G, Campos F \& Bloomquist J R (1995). Resistant to avermectins extent, mechanism and management implications. Annual Rewiev Entomology 40: 1-30

Çakmak İ \& Çobanoğlu S (2006). Amblyseius californicus (McGregor 1954) (Acari: Phytoseiidae), a new record for the Turkish fauna. Turk Journal Zoology 30: 55-58

Dekeyser M A (2005). Review acaricide mode of action. Pest Management Science 61: 103-110

Dunley J E, Messing R H \& Croft B A (1991). Levels and genetics of organophosphate resistance in Italian and Oregon biotypes of Amblyseius andersoni (Acari:Phytoseeidae). Journal of Economic Entomology 84: 750-755

Fournier D, Cuany A, Pralavorio M, Bride J M \& Berge J B (1987). Analysis of methidathion resistance mechanisms in Phytoseiulus persimilis A.H. Pesticide Biochemistry and Physiology 28(2): 271-278

Fritz L C, Wang C C \& Gorio A (1979). Avermectin B1A irreversibly block post synaptic potentials at the loboster neuromuscular-junction by reducing muscle membrane resistance. Proc Natl Acad Science 76: 2062-2066

Goka K \& Takafuji A (1992). Enzyme variations among Japanese populations of the two-spotted spider mites, Tetranychus urticae Koch. Applied Entomology Zoology 27: 141-150

Gotoh T, Tsuchiya A \& Kitashima Y (2006). Influence of prey on developmental performance, reproduction and prey consumption of Neoseiulus californicus (Acari: Phytoseiidae). Experimental Applied Acarology 40: 189-204
Kim Y J, Lee S H, Lee S W \& Ahn Y J (2004). Fenpyroximate resistance in Tetranychus urticae (Acari: Tetranychidae): cross-resistance and biochemical resistance mechanisms. Pest Management Science 60(10): 1001-1006

Kim Y J, Park H M, Cho J R \& Ahn Y J (2006). Multiple resistance and biochemical mechanisms of pyridaben resistance in Tetranychus urticae (Acari:Tetranychidae). Journal of Economic Entomology 99(3): 954-958

Kumral N A, Gencer N S, Susurluk H \& Yalcin C (2011). A Comparative evaluation of the susceptibility to insecticides and detoxifying enzyme activities in Stethorus glvifrons (Coleoptera: Coccinellidae) and Panonychus ulmi (Acarina: Tetranychidae). International Journal of Acarology 37(3): 255-268

LeOra Software (1994). Polo-pc: a user's guide to probit or logit analysis leora software. Berkeley p. 28

Mugo H M, El-Banhawy E M, Irungu L W, Ndegwa P N \& Mburu D N (2011). Resistance of predacious mite, Euselus kenyae (Acari: Phytoseiidae) to chlorpyrifos (Dursban) in kenyan coffee farms. Jagst 13(1): 53-64

Nicastro R L, Sato M E \& Silva M Z (2010). Milbemectin resistance in Tetranychus urticae (Acari: Tetranychidae): selection, stability and cross-resistance to abamectin. Experimental Applied Acarology 50: 231-241

Pottelberge S V, Leeuwen T V, Khajeali J \& Tirry L (2009). Genetic and biochemical analysis of a laboratory-selected spirodiclofen-resistant strain of Tetranychus urticae Koch (Acari:Tetranychidae). Pest Management Science 65: 358-366

Rose R L, Barbhaiya R, Roe G, Rock E \& Hodgson E (1995). Cytochrome P-450-associated insecticide resistance and the development of biochemical diagnostic assays in Heliothis virescens. Pesticide Biochemistry and Physiology 51: 178-191

Sato E M, Miyata T, Kawai A \& Nakano O (2000). Selection for resistance and susceptibility to methidathion and cross resistance in Amblyseius wormersleyi Schicha (Acari: Phytoseiidae). Applied Entomology Zoology 35(3): 393-399

Sato E M, Miyata T, Kawai A \& Nakano O (2001). Methidathion resistance mechanisms in Amblyseius womersleyi Schicha (Acari: Phytoseiidae). Pesticide Biochemistry and Physiology 69: 1-12

Sato M E, Silva M Z, Raga A \& Filho M F S (2005). Abamectin resistance in Tetranychus urticae Koch 
(Acari: Tetranychidae): selection, cross-resistance and stability of resistance. Neotropic Entomology 34: 991-998

Sato E M, Tanaka T \& Miyata T (2006). Monooxygenase activity in methidathion resistant and susceptible populations of Amblyseius wormersleyi Schicha (Acari: Phytoseiidae). Experimental Applied Acarology 39: 13-24

Sayyed A H, Pahtan A K \& Faheem U (2010). Crossresistance, genetics and stability of resistance to deltamethrin in a population of Chrysoperla carnea from Multan, Pakistan. Pesticide Biochemistry and Physiology 98: 325-332

Sökeli E, Ay R \& Karaca İ (2007). Determination of the resistance level of two-spotted spider mite (Tetranychus urticae Koch) populations in apple orchards in Isparta province against some pesticides. Tarım Bilimleri Dergisi-Journal of Agricultural Sciences 13(4): 326-330

Stumpf N \& Nauen R (2001). Cross-resistance, inheritance and biochemistry of mitochondrial electron transport inhibitor-acaricide resistance in Tetranychus urticae (Acari: Tetranychidae). Journal of Economic Entomology 94: 1577-1583

Stumpf N \& Nauen R (2002). Biochemical markers linked to abamectin resistance in Tetranychus urticae (Acari: Tetranychidae). Pesticide Biochemistry and Physiology 72: 111-121

Stumpf N, Zebitz P W, Kraus W, Moores G D \& Nauen $R$ (2001). Resistance to organophosphates and biochemical genotyping of acetylcholinesterases in Tetranychus urticae (Acari: Tetranychidae). Pesticide Biochemistry and Physiology 69: 131-142

Suh E, Koh S H, Lee J H, Shin K I \& Cho K (2006). Evulation of resistance pattern to fenpyroximate and pyridaben in Tetranychus urticae collected from greenhouses and apple orchards using lethal concentration-slope relationship. Experimental and Applied Acarology 38: 151-165

Tirello P, Pozzebon A \& Duso C (2012). Resistance to chlorpyriphos in the predatory mite Kampimodromus aberrans. Experimental Applied Acarology 56: 1-8
Tsagkarakou A, Navajas M, Rousset F \& Pasteur N (1999). Genetic differentiation in Tetranychus urticae (Acari: Tetranychidae) from greenhouses in France. Experimental Applied Acarology 23: 365-378

Yorulmaz S \& Ay R (2009). Multiple resistance, detoxifying enzyme activity, and inheritance of abamectin resistance in Tetranychus urticaeKoch (Acarina: Tetranychidae). Turkish Journal of Agriculture and Forestry 33: 393-402

Yorulmaz S \& Ay R (2012). Isparta ili elma bahçelerinden toplanan avc1 akar Neoseiulus californicus (Acari: Phytoseiidae) popülasyonlarının bazı akarisitlere karş1 direnç düzeyleri ve direnç mekanizmaları. Süleyman Demirel Üniversitesi Fen Bilimleri Enstitüsü Dergisi 16(2): 122-132

Yorulmaz S, Kaplan P, Boztürk D, Çobanoğlu S \& Ay $R$ (2010). Isparta ili elma bahçelerinden toplanan Tetranychus urticae Koch. (Acarina: Tetranychidae) popülasyonlarının cyhexatin ve propargite karşı duyarlılıklarının belirlenmesi. Süleyman Demirel Üniversitesi Ziraat Fakültesi Dergisi 5(1): 17-23

Van Leeuwen T, Stıllatus V \& Tirry L (2004). Genetic analysis and cross-resistance spectrum of a laboratoryselected chlorfenapyr resistant strain of two-spotted spider mite (Acari: Tetranychidae). Experimental and Applied Acarology 32: 249-261

Van Leeuwen T, Pottelberge S V \& Tirry L (2005). Comparative acaricide susceptibility and detoxifying enzyme activities in field-collected resistant and susceptible strains of Tetranychus urticae. Pest Management Science 61: 499-507

Van Leeuwen T, Vontas J, Tsagkarakou A, Dermauw V \& Tirry L (2010). Acaricide resistance mechanism in the two spotted spider mite Tetranychus urticae and other important Acari: A rewiev. Insect Biochemistry and Molecular Biology 40: 563-572

Winer B J, Brown D R \& Michels K M (1991). Statistical principles in experimental design. Third edition, ISBN 0-07-070982-3, New York 